\title{
Juridical Review of Nickel Governance Law in Indonesia
}

\author{
Antonius Setyadi ${ }^{1}$, John Pieris ${ }^{2}$, Aartje Tehupeiory ${ }^{3}$ \\ \{setyadiset60@gmail.com\} \\ Faculty of Law, Universitas Kristen Indonesia
}

\begin{abstract}
This study aims to conduct a Juridical review of the Mineral and Coal Mining Industry Governance Law in Indonesia, especially the Nickel Industry, from the perspective of legal typology by Nonet and Selznick and from the perspective of the Sociological Jurisprudence of Roscoe Pound. Changes that occur in the Mineral and Coal Mining Law in Indonesia can illustrate what is meant in the legal typology, from Nonet and Selznick, namely repressive, autonomous and responsive. This is to understand how Indonesia, as a sovereign country, is in the process of being responsive in making laws to achieve the welfare of the Indonesian people as the main goal. Also from Pound's perspective, this research helps to understand how the formation proceeds based on experience, and takes into account the theory of interest, to form a social pattern, for the ultimate goal as stated in the 1945 Constitution Article 33 paragraph (3).
\end{abstract}

Keywords: Mineral and Coal Mining Law; Sociology Jurisprudence; Legal Typology

\section{Introduction}

Nickel has become a very important and phenomenal commodity nowadays. The biggest nickel consumer globally is Asia, followed by Europe. [1] A few years ago, the world began to realize that nickel is a very important component for the manufacture of batteries, which are needed by the electric car industry. In the last decade, Indonesia exports lots of nickels because of its high demand. [2] From the very beginning, in the Law that was stipulated by the Dutch East Indies government in the Indische Mijnwet 1899 Number 214, jo Staatsblad 1904 Number 343 which replaced the Mijn Reglement 1850, there is a rule which shows that what is meant by energy sources is only coal, oil, and natural gas, while other minerals, including nickel, are included in minerals used for industrial purposes, but this type of commodity now being phenomenal. The long history of mining activities in Indonesia shows that although mining is a non-renewable source, Indonesia is an area that has enormous natural wealth, including the type of mineral wealth.

In 1899 there was a regulation regarding mining called the Indische Mijnwet, Staatsblad 1899 Number 214. The rules made by the Dutch East Indies government were intended to specifically regulate public permits in the mining sector, which were regulated according to the concept of Western Civil law. with the aim of political interests and colonial policies over the natural wealth of minerals in Indonesia based on their liberalistic and capitalist perspectives. Hence after Indonesia became sovereign, a regulation was needed to replace what was previously set by the Dutch colonial government so that Indonesia could have full power for its natural wealth, and not to serve the interests of the Dutch.[3] in relation to policy and its implementation, it still has many problems thus, the government need to be more consistent 
when applying it[4]. In the study conducted by Suherman and Saleh (2018) found out that there is an interrelated success between the value-added improvement policy from the Ministry of Energy and Mineral Resources and the downsreaming policy from the Ministry of Industry.[5] In the past few years, the production of nickel increased rapidly.[6] This has made the investor interested to invest in Indonesia.[7]

Since Indonesia's independence in 1945, this nation has a major task in affirming sovereignty over the land and natural resources contained therein. Therefore, in 1959, the Indonesian government issued Law Number 10 of 1959 concerning Cancellation of Mining Rights, the establishment of which was carried out due to several considerations, including that the method of cancelling mining rights as regulated in the applicable Indische Mijnwet could no longer be used, then a particular law is needed. Then in 1960, the Indische Mijnwet was revoked with the promulgation of Law Number 37 Prp. 1960.

Furthermore, in 1967, the Indonesian government issued Law Number 11 of 1967 concerning Basic Mining Provisions which were made with consideration, namely: "that to accelerate the implementation of national economic development towards a just and prosperous Indonesian society materially and spiritually based on Pancasila it is necessary to mobilize all funds and resources to cultivate and develop all potential economic forces in the mining sector into real economic forces.

Then, in the process of perfecting it, in 2009, the Indonesian government issued Law Number 4 of 2009 concerning Minerals and Coal to become the highest legislation after the constitution. Since being enacted in 2009, this Law has encountered many obstacles in its implementation, such as restrictions on foreign ownership of shares, the obligation to process mining products in the country, as well as the transfer of concessions from the Contract of Work system (KK/Kontrak Kerja) and Coal Mining Concession Work Agreement (PKP2B/ Perjanjian Karya Pengusahaan Pertambangan Batubara) into a form of Mining Business Permit (IUP/Izin Usaha Pertambangan).

As for the derivative or supporting regulations, a number of regulations/implementation instructions are in the form of Government Regulations, Regulations of the Minister of Energy and Mineral Resources, Regulations of the Minister of Finance and Regulations issued by the Director General of Mineral and Coal. The following figure shows the supporting rules:

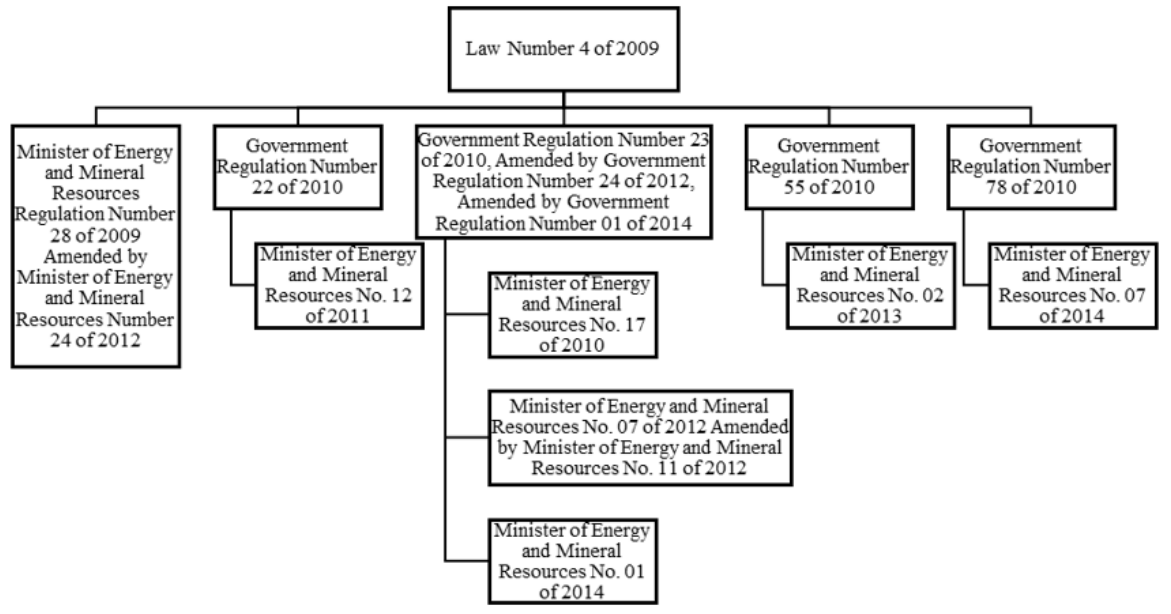

Fig 1. Hierarchy of Regulations Related to Mineral and Coal Mining Law Number 4 of 2009 
There are several provisions in the Mineral and Coal Law that are not easy to implement or experience inconsistencies in their implementation, for example regarding the policy of increasing added value by processing and refining minerals in the country. Also, regarding the licensing mechanism for smallholder mining and rock mining permits which are considered difficult to implement. And there are things that are considered no longer in accordance with the times and no longer in line with other laws such as Law Number 23 of 2014 concerning Regional Government. This relates to the arrangement of the division of affairs of the central government and regional governments as well as the authority to regional heads in the issuance of mining business permits.

Furthermore, in May 2020, the government issued Law Number 3 of 2020 concerning Amendments to Law Number 4 of 2009 concerning Mineral and Coal Mining. From historical developments and considerations in the formation of the Mineral and Coal Law, the government continues to make improvements regarding the implementation of the Mineral and Coal Law. On the other hand, in the same year, the Job Creation Law, known as the Omnibus Law, was enacted, which among other things contained regulations for mining business activities, especially those related to licensing clusters and several other arrangements which were also regulatory material in the Mineral and Coal Law. The Omnibus Law is a program to simplify, trim and harmonize the arrangement of more than one cluster in one law. Omnibus Law is a statutory regulation that contains more than one (cluster) regulatory content.[8] According to the Government, the Omnibus Law through the Job Creation Act is intended to address the problem of overlapping arrangements and provide investment convenience to create jobs, including in the Mineral and Coal mining sector.

The Omnibus Law for mining clusters consists of provisions that regulate Law Number 4 of 2009 concerning Mineral and Coal Mining, Law Number 22 of 2001 concerning Oil and Gas, Law No. Law Number 21 of 2014 concerning Geothermal, and Law Number 30 of 2009 concerning Electricity. The mining cluster Omnibus Law contains the authority to control minerals and coal by the state which is held by the Central Government (Licensing authority in the Central Government) and can be delegated to local governments. The division of authority for mineral processing and refining between the Ministry of Energy and Mineral Resources and the Ministry of Industry, namely mining to processing activities require an IUP, refining activities require an industrial business permit (IUI/ Izin Usaha Industri), and redefinition of the words "processing" and "refining" in the Mineral Law and Coal. In addition, there are incentives for downstream coal in the form of gasification in the form of not being subject to Domestic Market Obligation (DMO) obligations, the imposition of $0 \%$ coal royalties, and the term of the permit for the life of the mine. The incentive for mineral down streaming is in the form of an extension of the permit period for the life of the mine. [9]

In particular, this research is focusing on Nickel mining, as Nickel is currently experiencing increasing interest, especially from foreign investors. Foreign investors are trying to get this type of Nickel commodity, which is one of the components to make Lithium batteries for the needs of making electric cars. Indonesia is ranked first in the world for the amount of nickel resources. Indonesia is said to have nickel resources of $23.7 \%$ of the world's total nickel resources, followed by Australia with a percentage of 21.5\%, Brazil 12.4\%, Russia 8.6\%, and others.[10] This is in line with Nursahan, Isnaniawardhani, and Sulaksana stated that nickel is a leading commodity in Indonesia.[11].

In general, Nickel is available in all soil types and meteorites and also erupts from volcanic emissions. In the environment, nickel is bound with oxygen or sulfur and forms of oxides or sulfides in earth crust.[12] It is also as a transition element extensively distributed in the environment, air, water, and soil. [13] Nickel is as an alloy component for applications which 
have a requirement for lightness, strength, ductility, corrosion and aspect. [14] Nickel is a mutagen in some mammalian mutagenesis assays but not in bacterial assays.[15] Nickel is a naturally occurring element that exits in diverse mineral forms. [16]

Along the way, there are problems in this Mineral and Coal legislation. In accordance with Law Number 4 of 2009 and Government Regulation Number 1 of 2017 concerning the Implementation of Mineral and Coal Mining Business Activities, the government provides concessions for the export of raw minerals to mining entrepreneurs, for 5 years until from Government Regulation Number 1 which should be until January 12, 2020 with several conditions: (1) Changing the Contract of Work (KK/ Kontrak Karya) permit into a Mining Business Permit (IUP/ Izin Usaha Pertambangan) or a Special Mining Business Permit (IUPK/Izin Usaha Pertambangan Khusus); (2) After changing the permit, the mining entrepreneur must build a smelter or refinery within five years.

However, in the Minister of Energy and Mineral Resources Regulation Number 11 of 2019, the Government prohibits the export of nickel ore effective as of January 1, 2020, which should be valid until January 12, 2022. This caused a negative reaction from the European Union, which through the WTO filed a lawsuit. Inconsistent regulations regarding export bans and inconsistent downstream nickel products can be seen in the following chart:

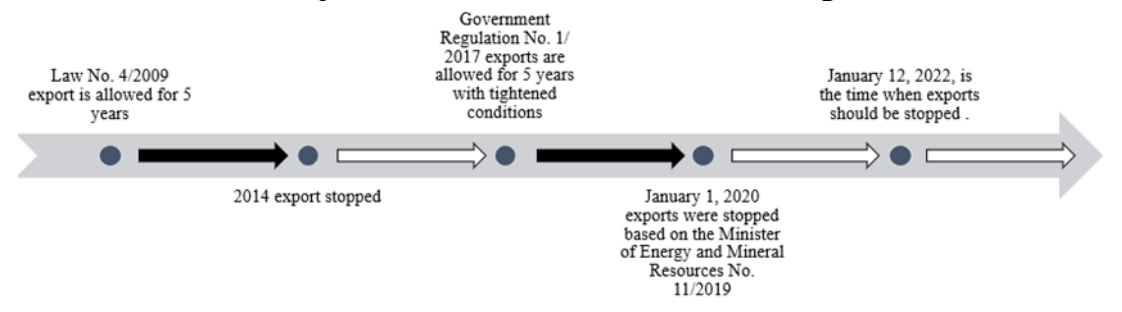

Fig. 2. Inconsistency of Nickel Raw Ore Export Prohibition Regulations

Based on Figure 2, it can be seen that there is a flow that shows the inconsistency of the rules regarding the export ban. In Law Number 4 of 2009, exports are allowed for 5 (five) years, then in 2014 exports were stopped. Furthermore, as regulated in Government Regulation Number 1 of 2017, exports are reopened for 5 (five) years, it means exports should have stopped on 12 January 2022. Yet not even five years, in 2020 this export has been stopped based on the Regulation of the Minister of Energy and Mineral Resources Number 11 of 2019.

\section{Results and Discussion}

\section{Changes in Rules in the Nickel Mining Industry Are Linked to the Legal Typology of Nonet and Selznick.}

Nonet and Selznick suggested three types of legal order, which to some extent can be seen as a continuum indicating a development of the legal order in a society that has a political organization in a form of state. The three types of legal order are: (1) repressive legal order; (2) Autonomous Legal Order and (3) Responsive Legal Order.[17] Repressive law is about how the law exercises its power for the benefit of the ruler who is currently in power. Nonet \& Selznick mention that government power is said to be repressive, if the power does not pay attention to the interests of the people under its government, or in other words, power tends to be exercised not for the benefit of the community, or by denying the legitimacy of the community. 
The basic idea of autonomous law is that the law is a separate institution capable of subduing repression and protecting its integrity. In repressive law, the law serves power, but in autonomous law, emphasis is placed on controlling repressive powers. This autonomous law views that the rule of law is a resource for carrying out the repressive law. Meanwhile, responsive law is an activity of modern legal theory that is constantly being studied, as stated by Jerome Frank, an American legal philosopher and author who played a leading role in the legal realism movement. The main goal of adherents of legal realism is to make the law more sensitive or more responsive to social needs. They explain that the law will give its own form in society. The rationale is that developing countries have their own characteristics of problems, so they cannot be forced to follow established ways of administering law in Western countries.

This typology of law from Nonet and Selznick is a form of modern law whose development is influenced as the modern state exists and develops. In the development of this legal typology within a country, the transition from autonomous to responsive can be seen from the ability to generalize the objectives of the law. Certain policy rules and procedures are considered instruments and can be adapted. In this case, the factor that is easy to see is whose interests will be fulfilled by the legal adjustment. Therefore, what characterizes responsive law is the search for implicit values that exist in rules and policies.

In this case, the Mineral and Coal Law that we are discussing will be reviewed from the point of view of utilitarianism as described in the previous chapter. Nonet and Selznick here emphasize Jerome Frank's thinking that the main goal of legal realists is to make law more responsive to social needs. Therefore, the relevant areas to reach the law should be expanded, so that the legal mindset can include knowledge of the social context and the impact of government policies or actions.

Amendments to the Mining Law made from Law Number 4 of 2009 to Law Number 3 of 2020 concerning Amendments to Law Number 4 of 2009 concerning Mineral and Coal Mining, contain many points of change. The changes listed in this chapter are only partial changes to show how these changes can be understood from the perspective of Nonet and Selznick's legal typology. Nonet and Selznick in their typology focus on the process that occurs when a nation still has to face basic problems (such as building a nation or a new political order).

Considering the perspective of Nonet and Selznick's legal typology, the changes that occur in the Mining Law in Indonesia can illustrate what is meant by legal typology. The changes that occurred in Law Number 4 of 2009 to Law Number 3 of 2020, through the stages of the formation of laws, are in line with the thoughts of the Indonesian government which show responsiveness in the formation of laws. Law Number 3 of 2020 is the latest Mineral and Coal Law, which has undergone a long process, especially when viewed from the history of the Mineral and Coal Law in Indonesia. The process of improving the previous Mining Law, namely Law Number 4 of 2009 through the improvement of the Draft Law which was carried out through intensive discussion of the Inventory List of Mineral and Coal Bill Issues with the Government from mid-February to early May 2020.

Thus, changes to the Mining Law seen from the perspective of Nonet and Selznick's legal typology can be understood by looking at the essence of the intended interests. When a country begins to regulate its laws and regulations, the tendency is to serve the interests of the authorities, in this case the law can be seen as repressive. But in a state that leads to a modern state, it will be more responsive to the interests of the community. To some extent, from this, we can see to what extent the importance of the law takes precedence over describing how modern the country is. 


\section{Changes to the Mining Law Seen from the Sociological Jurisprudence Perspective of Roscoe Pound.}

Sociological jurisprudence initiated by Roscoe Pound [18] is a school in legal philosophy that studies the reciprocal relationship between law and society. Sociological jurisprudence has an approach that starts from law to society. This school emphasizes the importance of living law in society, and that only laws that are able to face the test of reason can survive, meaning that the only eternal elements in the law are logical statements that stand above them. experience and honed by experience. [19] He stated that "Law is an experience regulated and developed by reason, promulgated with authority by the bodies that make laws or pass laws in a society that is politically organized and assisted by the power of that society."

Pound's sociological jurisprudence refers more to practical matters, namely how the law is implemented. Pound is also a person who supports pragmatic legal realism, that the real law is the law that is implemented. This law is not only in the form of writing in the Act, but also the actions and what are carried out by law administrators and carry out the function of implementing the law with its legal concept, namely law that can act as a means of changing society (law as a tool of social engineering). Pound initiated a theory he called the Interest Theory, that the law is a set of certain interests (certain interests), which according to society, these interests must be protected by law. In this sense, the interests that must be protected by law are not all interests, because there are certain interests that can be protected by religion, morals and aesthetics, etc.

The concept of Social Engineering (social engineering) which was initiated by Pound can be said to be the main idea of the other ideas put forward by Pound. Its main objectives are: "to construct as efficient a structure of society as possible which requires the satisfaction of wants with the minimum of friction and waste of resources. It means Law should work for balancing of competing interests within the society for the greatest benefit." [20] The basis of this regulation in Indonesia is the 1945 Constitution Article 33 paragraph (3) which states that "Earth and water and the natural resources contained therein are controlled by the State and used for the greatest prosperity of the people". Indonesia is fully sovereign over the wealth of its natural resources, and this natural wealth must be used for the greatest prosperity of the people, which is interpreted as legal ownership rights to natural wealth for the Indonesian people. This means that the right of state control is an instrument, and 'the greatest prosperity of the people' is the ultimate goal of natural wealth management. [21]

The meaning of being controlled by the state is that the natural wealth in the territory of Indonesia is the authority of the government to determine the use, utilization, and rights to natural resources within the scope of regulating, administering, managing and supervising the management and utilization of natural resources. Indonesia is so rich in nature, including the content in the soil, that not all of its exploitation can be carried out by the state. This understanding becomes the basis that the private sector cannot have monopoly rights in controlling, exploiting, and distributing mining business products, because this is contrary to the state constitution and can hinder the purpose of the 1945 Constitution Article 33 paragraph 3 regarding to the maximum extent possible. people's prosperity. The position of the state in this case is as the owner of mining materials (principal), and the opponent of the contract is the executor of mining materials (contractor). Pound wants to change the law from the theoretical level (law in book) into reality (law in action). Therefore, Pound's sociological jurisprudence refers more to practical matters, namely how the law is implemented. 


\section{Legal Analysis}

Pound also states that Law is an experience governed and developed by reason, which is promulgated with authority by the bodies that make laws or pass laws in a society that is politically organized and assisted by the power of that society. The emphasis here is on the ability of the agency that makes and or ratify the law itself, including in this case the Mineral and Coal Law. Bearing in mind the existing experience, especially if it is related to the legal typology of Nonet and Selznick in the previous chapter, that the Indonesian people adjust their laws, as Indonesia shifts from a colonial economic system to a national economic system. In the mining sector, laws that were previously repressive in nature, which served the interests of the Dutch East Indies government, needed to undergo a process to become a law that was responsive to the welfare of the people. Pound in this case emphasizes the need to pay attention to interests in his Theory of Interest.

He stated that social interest is a clearer attempt to create a responsive legal model. The interests in question are of course the interests of the Indonesian people. Therefore, this amendment to the Mineral and Coal Law after the independence era, namely Law Number 1 of 1967, Law Number 4 of 2009, and finally Law Number 3 of 2020, must be based on experience regulated and developed by reason. This nation does not want to be careless in utilizing its resources, especially since it is a non-renewable energy, to be used detrimentally and does not support the prosperity of the people. The government needs to be careful that the laws that are regulated do not serve only a few parties, or even other nations, because this is not in accordance with the 1945 Constitution Article 33 paragraph (3).

Thus, legal experts and judges must be more flexible and open in understanding the law and must be able to accommodate changes that occur in society so that the law can be a link that creates harmonization in meeting the interests and aspirations of the community and minimizes social conflicts. If viewed from the perspective of Pound's sociological jurisprudence, it can be understood how the function of this law is dynamic in society, there are social values that are expressed in the law itself. The judicial task of judges is no longer understood simply as applying the law to factual events learned from various cases and conflicts but also as a social driver or social engineering. A society that needs to be mobilized and formed in this regard in connection with the habits that occur in the Nickel mining industry, in order to form a system and culture that supports the interests of Indonesian sovereignty, especially in this case, in accordance with the 1945 Constitution Article 33 paragraph (3), where Indonesia's natural wealth is processed by the State with the prosperity of the people being the main goal.

Regulation regarding mining in Indonesia is one of the crucial things to do. This is because mining is an important production branch for the state. The arrangements made in the Mineral and Coal Law Number 3 of 2020 which were just last year are arrangements for sustainable and responsible mining management that must provide added value for the prosperity of the people, fully carried out by the Government with the DPR. This means that the Government and DPR will continue to make adjustments in an effort to improve the mining sector so that it can make a real contribution to the community. This arrangement refers to the principles of benefit, environmental perspective, legal certainty, participation, and accountability.

A big implication of the rules made regarding mining, especially in the Nickel mining industry is the prohibition on the export of raw nickel ore, which has been banned since 2020, with the aim that the raw material is further processed to provide added value. The basis for this is the Minister of Energy and Mineral Resources Regulation Number 11 of 2019 concerning the Second Amendment to the Regulation of the Minister of Energy and Mineral Resources Number 25 of 2018 concerning Mineral and Coal Mining Concessions. In this case, the ban on the export of raw nickel or nickel ore is effective as of January 1, 2020, although the government later 
relaxed. However, later, the Ministry of Energy and Mineral Resources accelerated the ban on exports of nickel ore commodities, starting January 1, 2020, 2 (two) years earlier than the original plan.

This export ban applies to nickel ore grades below 1.7\%. Several reasons for the government to accelerate the ban, among others, are that low grade nickel ore can be processed domestically, due to advanced technological developments. Some parties feel disadvantaged by regulations regarding export bans such as mining companies and the buyer. Despite the interests involved in banning nickel ore exports, the government seems to be paying attention in the right way. This can be understood from the perspective of a larger welfare, namely the Indonesian nation and people. And this is in accordance with Article 33 paragraph 3 of the 1945 Constitution, as the highest basis used by miners. In the short term, the export ban is likely to slightly reduce Indonesia's export potential. However, in the long term, the export ban will have a positive impact on the economy as a whole. Because the export ban will increase investment in building smelters and downstream industries, most of which will be exported later.

In addition, what needs to be considered in Pound's thinking in relation to the ban on nickel exports is the point that the state's interest must be the highest or the highest because the state has national interests. The national interest must protect the interests of the state, in this case there is a phrase that the will of the state is the will of the public. Because the law is not as positivist theories say that the law has a closed nature. Law is strongly influenced by ideology, politics, economy, social, culture. It's not just the government's will.

Thus, it can be concluded that in order to understand the changes to the Mining Law from the perspective of Roscoe Pound's sociological jurisprudence, when the law is enforced, it produces a balance between these three interests, then this harmonious balance reflects the essence and justice. Since Indonesia became sovereign and independent in 1945, the Mineral and Coal Law in Indonesia has undergone several changes. This is intended to improve the welfare of the people by making a transition from a colonial economic system to a national economic system. This evolution should be understood as a process that takes into account various interests in line with Pound's theory of interests. Including special rules regarding the ban on exports of raw materials aimed at protecting the national economy, by inviting foreign investors to manufacture smelters, with multiple benefits as stipulated in Law Number 25 of 2007 concerning investment.

\section{Conclusion}

Changes in regulations in the nickel mining industry are related/ viewed from the perspective of legal typology from Nonet and Selznick can illustrate what is meant by legal typology. The earliest known Mining Law was the Indische Mijnwet 1899, which served as a repressive law, where this Act worked for the benefit of Dutch (foreign) private companies to obtain mining products from Indonesia under the Dutch East Indies government. It can be said that this law immediately served the interests of the rulers at that time without considering the welfare of the Indonesian people, who were actually the owners of the Indonesian homeland. Then at the time of Law Number 10 of 1959 concerning the cancellation of the Indische Mijnwet 1899, this Cancellation Act acted as an autonomous law that played a role in supervising the previous repressive law.

However, later, the regulations issued later, such as Law Number 1 of 1967, Law Number 4 of 2009, and Law Number 3 of 2020, which continue to make changes and improvements are 
a form of responsibility from the government, which aims to improve the national economy for the welfare of the Indonesian people. This is in accordance with Article 33 paragraph 3 of the 1945 Constitution, in this case the law can be categorized as responsive law in the Nonet and Selznick typology.

Changes in the rules in the nickel mining industry are related/ viewed from the perspective of Sociological jurisprudence initiated by Roscoe Pound referring to practical matters, namely how the law is implemented. The main function of law is to protect interests, namely public interests, social interests and personal interests. When the law that is enforced produces a balance for these three interests, it is this harmonious balance that reflects the essence and justice. This is seen from the evolution of Mineral and Coal law in Indonesia.

Since Indonesia became sovereign and independent in 1945, Indonesia has made several changes in many fields, including the Mineral and Coal Law. The point is the transition from a colonial economic system to a national economic system. This evolution should be understood as a process that takes into account various interests in line with Pound's theory of interests. Including special rules regarding the ban on exports of raw materials aimed at protecting the national economy, by inviting foreign investors to manufacture smelters, with multiple benefits as stipulated in Law Number 25 of 2007 concerning investment.

\section{References}

[1] A. Apostolikas, E. Frogoudakis, and J. Bakallbashi. Nickel, World Production and Demand. 3rd Balkan Mining Congress, BALKANMINE 2009, 1-3 October, øzmir-TURKEY, (c 2009, ISBN $978-$ 9944-89-782-2

[2] Ahmad Redi. Hukum Energi: Konsep, Sejarah, Asas, dan Politik Hukum. Depok, Rajawali Pers, 2020.

[3] Prasetyo, P. Tidak sederhana mewujudkan industry pengolahan nikel laterit kadar rendah di Indonesia sehbungan dengan Undang-Undang Minerba 2009. Jurnal Teknologi Mineral dan Batubara. 12(3). Pp. 195-207. 2017. 10.30556/jtmb.Vol12.No3.2016.139.

[4] Kompas. Retreived from: Plus Minus Omnibus Law Undang-Undang Cipta Kerja yang Sudah Disahkan Halaman all - Kompas.com. Accessed date: March 12, 2021.

[5] Ijang Suherman \& Ridwan Saleh: Supply Chain Analysis for Indonesian Nickel. Indonesian Mining Journal. Vol. 21, No. 1, april 2018: 59-76. DOI: 10.30556/imj.Vol21.No1.2018. 59-76

[6] Yunianto, B: Analisis dampak penerapan kebijakan nilai tambah mineral Indonesia terhadap ekspor dan tenaga kerja. Jurnal Teknologi Mineral dan Batubara, 10 (3). Pp.127-141. 2014

[7] Haryadi, H. Analisis Peranan Mineral dan Batubara bagi perekonomian nasional. Jurnal Teknologi Mineral dan batubara. 7 (3). Pp. 122-136. 2011.

[8] PUSHEP. Retreived from: Adu Cepat RUU Mineral and Coal dan Omnibus Law Sektor Pertambangan | PUSHEP, Accessed date: March 12, 2021

[9] Kompas. Retreived from: Plus Minus Omnibus Law Undang-Undang Cipta Kerja yang Sudah Disahkan Halaman all - Kompas.com. Accessed date: March 12, 2021.

[10] Umah, Anisatul. Mei 2021. Retreived from: RI Punya Harta Karun Tambang Terbesar di Dunia, Ini Faktanya (cnbcindonesia.com).

[11] Nonet, Philippe \& Philip Selznick. Law and Society in Transition: Toward Responsive Law, London: Harper and Row Publisher, 1978.

[12] Ignasius, L. dan Nurseffi, D.W. Ekspor Indonesia Turun 90\% dalam steelindonesia.com

[13] Nursahan, I., Isnaniawardhani, V. and Sulaksana, N. Penentuan kawasan pertambangan berbasis sektor komoditas unggulan sumberdaya nikel Kabupaen Konawe dan Konawe Utara, Provinsi Sulawesi Tenggara. Buletin Sumber Daya Geologi. 8(2), pp. 41-53. 2013. Available at http://buletinsdg.geologi.esdm.go.id/index.php/bsdg/issue/view/BSDG\%20Vol\%208\%20No\%202

[14] Kusal K. Das, R. Chandramouli Reddy, Ishwar B. Bagoji, Swastika Das, Shrilaxmi Bagali, Lata Mullur, Jyoti

[15] P. Khodnapur and M.S. Biradar. Primary concept of nickel toxicity - an overview. De Gryter. 2018 
[16] Giuseppe Genchi, Alessia Carocci, Graziantonio Lauria, Maria Stefania Sinicropi, \& Alessia Catalano. Nickel:

[17] Human health and environmental toxicology. International Journal of Environmental Research and Public Health. 2020

[18] John Stepan. An analysis of Nickel price variation and its impact on the global economy. Conference Paper.

[19] Nancy E. Lightfoot, Michael A. Pacey \& Sheley Darling. Gold, Nickel, and Copper Mining and Processing. 2015

[20] Chronic Desease in Canda. Vol. 29, Supplement 2, 2010. DOI: 10.24095/hpcdp.29.S2.03

[21] Roscoe Pound, Contemporary Juristic Theory, Claremont CA: Pamona College, 1940.

[22] Schaumlöffel, D. Nickel species: Analysis and toxic effects. J. Trace Elem. Med. Biol. 2012, 26, 16.

[23] Zainuddin Ali. Filsafat Hukum. Cet 9. Jakarta, Sinar Grafika, 2019.

[24] Sutedi Adrian. Hukum Pertambangan. Cet 2, Editor Tarmizi, Jakarta, Sinar Grafika. 2012. 